\title{
Endoplasmic Reticulum Export Factor CTAGE5
}

National Cancer Institute

\section{Source}

National Cancer Institute. Endoplasmic Reticulum Export Factor CT AGE5. NCI Thesaurus. Code C114659.

Endoplasmic reticulum export factor CTAGE5 (804 aa, $91 \mathrm{kDa}$ ) is encoded by the human CTAGE5 gene. This protein is involved in intracellular protein transport and tumor induced immune responses. 